\title{
Wstęp
}

\section{Porządki w bibliotece}

Anna Nasiłowska

TEKSTY DRUGIE 2019, NR 1, S. 7-12

DOI: 10.18318/td.2019.1.1 / ORCID: 0000-0002-6171-5662

dy robi się porządki w domowej bibliotece, ustawia się książki według autorów, serii wydawniczych i tematycznie, ale w końcu zawsze wychodzi na to, że jeszcze potrzebne są nowe kategorie: książki w dużych formatach, które nie mieszczą się na półce zgodnej z poprzednimi porządkami, i jeszcze te $w$ ładnych oprawach, które warto by wyeksponować. I cały porządek okazuje się dość problematyczny. Tematy, serie i autorzy to klasyfikacje nachodzące na siebie, format - to kategoria formalna, a "te ładne" - czysto uznaniowa. Przystępując do porządkowania gatunku biografii, pomyślałam, że dobrze by było zacząć od własnej biblioteki, w której nie ma regału "biografie", ale istnieje kilka "podzbiorów".

Jest na przykład taka kategoria, mieszcząca się nad kanapą, jak „biografie w językach obcych".Trudno tam nie zauważyć dwóch dzieł: Deirdre Bair, Simone de Beauvoir, stron 834 oraz David Bellos, Georges Perec, stron 802; pierwsza z nich po francusku, ale jest tłumaczeniem „z amerykańskiego angielskiego”, druga jest po angielsku (nie USA, wydana w Londynie przez Harvill Press). Mają kilka cech wspólnych - są to grube, oparte na badaniach źródłowych, studiach nad rękopisami i niepublikowaną korespondencją oraz na materiale z rozmów ze świadkami zdarzeń gruntowne opracowania historyczne, wymagające
Anna Nasiłowska prof. dr hab., historyczka literatury, pisarka, poetka. Jest autorką biografii: Jean-Paul Sartre iSimone de Beauvoir (WL 2006), Maria Pawlikowska-Jasnorzewska czyli Lilka Kossak (2010) i Wolny agent Umeda i druga Japonia (2013). Ostatnio opublikowała zbiór wierszy Ciemne przejścia (2018), w przygotowaniu wydawniczym tom Historia literatury polskiej. Kontakt: anna.nas@wp.p 
wielu lat pracy, a dotyczące dwojga pisarzy francuskich. )est też polski przykład (stojący więc na innej półce): Frederick Brown, Flaubert. W niewoli słowa i kobiet, stron 744. Trzy przykłady to za mało, aby dowodzić ogólnej tendencji, ale dodajmy do tego inne dzieła wymienionych autorów: Deirdre Bair jest również biografką Samuela Becketta, a także Carla Gustava Junga, Anaïs Nin i Saula Steinberga, a David Bellois - Jacques'a Tatiego i Romaina Gary'ego. Frederick Brown jest także autorem biografii Emila Zoli i Jeana Cocteau oraz dwóch książek poświęconych Francji. Oczywiście taki zestaw świadczy na pewno o moich zainteresowaniach literaturą francuską (choć to się zmienia, na tej samej półce stoi np. amerykańska biografia angielskiego krytyka Samuela Johnsona autorstwa Christophera Hibberta), ale i dowodem kilku ogólniejszych tendencji.

Po pierwsze biografia jest jednak specjalnością anglosaską; zwykle napisane po angielsku pozycje dotyczące francuskich pisarzy są tłumaczone na francuski. Ach, gdybyż nam napisali biografie! - można by westchnąć. Ale i tu mam przykład - oto gruba książka Adam Mickiewicz. Życie romantyka, autor: doskonale znany czytelnikom naszego pisma Roman Koropeckyj, profesor uniwersytetu Kalifornijskiego w Los Angeles. Polskie wydanie jest tłumaczeniem.

Po drugie musi istnieć bardzo silna specyfika gatunkowa biografii, skoro autorzy dzieł poświęconych jednej postaci sięgają po kolejnych bohaterów. Umiejętności warsztatowe, jakich wymaga uprawianie gatunku, są tu ważniejsze niż specjalizacja w twórczości pisarza. Jeśli ktoś opanuje warsztat biografa, polegający na poszukiwaniu materiałów archiwalnych i konstruowaniu z nich opowieści - często nie poprzestaje na jednej pozycji, dodaje do nich kolejne, sięgając po następnych bohaterów. Poza tym autora biografii obowiązuje obiektywizm, co zakłada konieczny dystans wobec bohatera; utożsamienie się z opisywaną postacią to uzurpacja, także bezwarunkowy podziw czy osobiste, sentymentalne uwikłanie (w obronę lub postawienie w stan oskarżenia) jest bardzo złym punktem wyjścia, w ten sposób mogą powstać jedynie apologia, pamflet lub polemika. Zrozumiałe więc, że autor biografii może po napisaniu książki porzucić temat, wobec którego był emocjonalnie zdystansowany. Z przedmów do książek można wyczytać, że zazwyczaj autorzy w trakcie pracy wspierani byli przez subwencje (czyli granty) różnych fundacji; książki są grube, czasem (ale nie nadmiernie) opatrzone przypisami i odnośnikami do archiwów. Poza tym sukces książki przekłada się zwykle na kolejne zamówienia wydawnicze - co dzieje się także i u nas, przykładem dwie biografie Andrzeja Franaszka.

Po trzecie biografa jest - mimo odniesień archiwalnych, rzetelności, badawczego charakteru - gatunkiem adresowanym do wielkiej publiczności, a nie tylko do specjalistów, co zawdzięcza swojej narracyjności. Im większa potencjalna publiczność - tym lepiej, pozycja biografii amerykańskiej bazuje na sławnych postaciach z tego kręgu kulturowego i ogromnej publiczności Stanów Zjednoczonych, Kanady i Australii. 
Każda z biografii adresowana jest do pewnej grupy czytelników, samodzielna pozycja rynkowa tego typu książek to szansa gatunku, ale i ograniczenie. Autor nie może przesadzić z wdawaniem się w specjalistyczne rozważania, powinien stworzyć coś równie zajmującego jak powieść.

Tłumaczenia biografii angielskich i amerykańskich obecne były na naszym rynku wydawniczym nawet w okresie zdecydowanej posuchy w biografiach polskich, choć zdarzało się, że tłumaczenie było skrótem. Obecny przełom w moim szkicu zamieszczonym w "biograficznym" numerze "Dekady Krakowskiej” (2/3, 2018) nazwałam anty-antybiograficznym. Złożyło się na niego kilka czynników. Przede wszystkim jest to pojawienie się prawdziwego rynku wydawniczego z jego presją, zmiana kierunku inspiracji kulturowych na orientację anglosaską oraz wygaśnięcie ujęć ideologicznie wykluczających biografizm, jak marksizm, proponujący wizję wielkich konfliktów klasowych, oraz osłabienie kierunków w badaniach literackich kładących nacisk na czysto immanentne podejście do tekstu literackiego. Badania nad biografiami zawsze były uprawiane, ich efekty prezentowano w postaci przyczynków, ale nie tylko. Wykształcił się u nas model nie-narracyjny, kronikarski, przykładem książki Józefa Szczublewskiego (Henryk Sienkiewicz, Żywot Osterwy), Wiktora Woroszylskiego o Majakowskim czy biobibliografia Marii Kuncewiczowej Alicji Szałagan. Barierą dla polskich badaczy była długo niemożność zrobienia stopnia naukowego na podstawie pracy o charakterze narracyjnym, co się zmienia, choć jedynym uznanym gatunkiem (mniejsza o definicję) pozostaje "monografia".

Mamy więc kolejny podział: biografie mają postać kroniki lub mogą być narracyjne, istnieją też przyczynki biograficzne (naukowe i eseistyczne), nieproponujące całościowej opowieści, ale wskazujące punktowo na jakieś nowe fakty, odkryte w wyniku podjętych poszukiwań (przykład naukowy: Stanisław Trembecki w świetle nowych źródeł Edmunda Rabowicza). W biografii narracyjnej zazwyczaj dominuje chronologia od czasu narodzin po śmierć, na co nakłada się układ tematyczny. Na przykład w biografii Gombrowicza Klementyny Suchanow na chronologię nakładają się odniesienia topograficzne (koniec tomu drugiego to rozdziały: Przez Paryż do Berlina i z powrotem, Vence). W biografii Iłłakowiczówny pióra Joanny Kuciel-Frydryszak mamy - prezentowany chronologicznie - porządek miejsc i odniesień wobec osób odgrywających kolejno rolę w życiu poetki, jak na przykład w rozdziałach: Matka Zofia. W Inflantach; Na służbie. U Marszałka; W Klużu. Obca.Znalezienie względnie neutralnego, łatwego do odszyfrowania zespołu odniesień organizujących biografię bohatera nadaje porządek książce, ułatwia czytelnikowi orientację i musi wynikać z etapów życia postaci. Z kolei w biografii Miłosza autorstwa Franaszka jako tytuły podrozdziałów pojawiają się cytaty z wierszy, co podkreśla związek z twórczością i autointerpretacjami swojego losu autora Poematu o czasie zastygłym. 
Odrzucenie chronologii jest typowe dla eseju biograficznego, na przykład w mickiewiczowskim cyklu Jarosława Marka Rymkiewicza tematem opowiadania są prowadzone przez autora książki poszukiwania, co podkreśla figura porządkowania fiszek. Esej biograficzny może być polemiką z ustalonymi wersjami biografii, a także z biografizmem jako podejściem, tu przykładem jest znakomita książka Janet Malcolm Milcząca kobieta. Sylvia Plath i Ted Hughes, pokazująca, jak ciekawość poszukiwaczy sensacji nie pozwoliła dostrzec oczywistych faktów. W eseju biograficznym „ja” piszącego jest na pierwszym planie, Janet Malcolm może więc opowiedzieć, jak pewnego dnia jechała samochodem i co w trakcie jazdy mówili towarzysze podróży, a także jakie były jej uczucia, gdy zetknęła się z otoczeniem poetki. Autor biografii - jeśli w ogóle używa "ja"- powinien umieścić je na dalekim planie, jako kontrapunkt do losów zasadniczego bohatera. Ja w moich biografiach kilkakrotnie odwoływałam się do takiego toposu, uznając, że na przykład dodanie własnego zdziwienia ożywi opowieść, ale żadna z tych książek nie była pracą akademicką.

Biografie różnią się też kilkoma innymi cechami. W tych pisanych przez badaczy literatury lub historyków panuje podejście eksponujące dokument, zwłaszcza w postaci tekstu (wraz z konieczną krytyką źródeł); istnieją jednak biografie, zwłaszcza pisane przez dziennikarzy, które za cel stawiają sobie ubarwienie opowieści fikcyjnymi dialogami ilustrującymi przebieg życia bohatera, a opartymi zaledwie na prawdopodobieństwie, i wyobrażeniami osoby piszącej, niekiedy nieznośnie denerwującymi. Mamy tu więc: „Ach, westchnęła, oblewając się rumieńcem" i „odparł bez pardonu”. Chwytem posługuje się gęsto Marta Sztokfisz, autorka niedawno wydanej książki Pani od obiadów. Lucyna Ćwierczakiewiczowa. Historia życia. Tak wygląda współczesne wcielenie gatunku la vie romancée, czyli biografii powieściowej, o którym wspominam w artykule o międzywojennych tradycjach. Im bardziej popularne ujęcie, tym silniejsza chęć ozdobienia i umilenia lektury książki w takiej lub innej formie, za pomocą dialogów, ilustracji, sztukowania, wstawek, by wytworzyć wreszcie opowieść bliską strukturze powieści z narratorem wszechwiedzącym, choć autorowi biografii do wszechwiedzy daleko. Wydana u nas przed laty, poświęcona biografistyce książka Jamesa L. Clifforda Od kamyków do mozaiki w oryginale nazywa się: From puzzles to portraits. Wolę anglojęzyczną metaforę: wiedza uzyskana na podstawie dokumentów jest punktowa, to układanka, z której trzeba złożyć jakiś obraz, narracja może maskować białe punkty, ale autorzy książek adresowanych do dużej publiczności często „sztukują" własną niewiedzę domysłami.

Narracja sama w sobie jest konstrukcją, w każdej biografii, także opartej na rzetelnym stosunku do dokumentów, nazwijmy ją biografią źródłową, jest jednym z punktów, które bez trudu dałoby się podważyć, używając narzędzi filozoficznych. Skoro u Haydena White'a w stan podejrzenia postawione zostały źródła, to wytworzona na podstawie źródeł opowieść multiplikuje zawarte w nich uzurpacje. Ale jakoś radzić sobie trzeba. 
Ja radzę sobie za pomocą odwołania do Ricoeura, który narrację uznawał za figurę rozumienia; co opowiedziane - to zrozumiane i możliwe do przekazania czytelnikowi. Są też inne pomysły, jak na przykład odejście od bohatera indywidualnego na rzecz zbiorowego. Daje to jednak niezbyt przekonujące efekty, jak się to dzieje w pracy Marci Shore Kawior i popiół. Życie i śmierć pokolenia oczarowanych i rozczarowanych marksizmem, mimo znakomitych źródeł i nowych faktów. Nasze rozumienie świata jest personalne, opiera się w swoim podstawowym wymiarze na relacjach wobec osób. Jan Józef Lipski pisał kiedyś, że ujęcie biograficzne jest związane z kręgiem kultury śródziemnomorskiej. Rzeczywiście da się wskazać antyczne, grecko-rzymskie źródła gatunku, ale sprawa jest jeszcze bardziej podstawowa, biografizm odwołuje się do podstawowych reguł percepcji, sposobu rozumienia relacji międzyludzkich.

Biografie różnią się pod względem gruntowności badań, sposobu ujęcia, relacji do życia prywatnego i uwzględniania (lub nie) twórczości; niektóre chcą być monografią totalną postaci, inne stawiają sobie za cel popularyzację lub przyjmują postawę polemiczną, jak na przykład biografia Dzierżyńskiego Sylwii Frołow, poświęcona młodości twórcy sowieckich służb bezpieczeństwa. Polemika może mieć różny charakter, przeważnie jest ukryta, wystarczy, że biografia przeciwstawia się stereotypowi (jak Dzierżyński = morderca). Zasadą ukrytą gatunku pozostaje jednak znane nazwisko postaci, której dotyczy. Największy kunszt biografa nie wykreuje postaci, jeśli nie była ona już wcześniej rozpoznawalna, można co najwyżej doczepić do celebryty/tki żonę, męża, przyjaciółkę, mecenasa. Pisanie pamiętników jest bardziej demokratyczne, może je stworzyć każdy świadek historii. Biografie można opisywać, biorąc pod uwagę trzy aspekty: badawczy, a więc historyczny czy historyczno-literacki, reporterski i narracyjny; zwykle współistnieją one w książce, a dominacja któregoś z nich określa typ biografii.

Dla mnie uprawianie biografistyki stało się pewną szansą przekroczenia hermetycznego literaturoznawstwa akademickiego. Zawsze wydawało mi się, że trzeba to robić; humanistyka jest zbyt ważna, by pozostawić ją wyłącznie specjalistom czy zamknąć w kręgu akademickim; tymczasem wyczerpały się możliwości uprawiania krytyki literackiej. A tu da się wydać książkę, która ze względu na spory nakład sama się sfinansuje, a nawet może pomóc sfinansować różne marzenia. Na przykład honorarium za biografię Pawlikowskiej-Jasnorzewskiej przeznaczyłam na wycieczkę do Kioto (nie z Polski, z Tokio). To piękne móc zamienić swoją pracę pisarską na doznanie harmonii i po drodze zobaczyć (na mgnienie, z pędzącego shinkansena) górę Fuji. Co prawda praca trwała kilka lat, a wycieczka trzy dni, ale tamte widoki mam wciąż pod powiekami. A potem okazało się, że te doświadczenia były mi bardzo potrzebne do napisania kolejnej biografii, tym razem poświęconej dwóm zasłużonym dla Polski Japończykom. 


\section{Abstract}

\section{Anna Nasiłowska}

THE INSTITUTE OF LITERARY RESEARCH OF THE POLISH ACADEMY OF SCIENCES (WARSAW)

Tidying up the Library

Nasiłowska classifies different types of biography: narrative biography and chronicle, the biographical essay, the biographical novel, source biography, contributions to a biography. She highlights the specificity of the genre and the way of shaping a narrative, and she also draws attention to the genre's current popularity in Poland as an expression of market changes. Biography, which addresses a broad readership, has strong ties to the publishing industry and its writers include not only researchers but also journalists.

\section{Keywords}

narrative biography, biographical essay, biographical novel, source biography, biographical contribution, chronicle 